\title{
PENGARUH METODE LATIHAN DAN MOTIVASI BERPRESTASI TERHADAP KETERAMPILAN TEKNIK DASAR FUTSAL
}

\author{
Oleh \\ Risa Hadi ${ }^{1}$ \\ ${ }^{1}$ Universitas Muhammadiyah Cirebon \\ Email: risa.hadi88@gmail.com
}

\begin{abstract}
Abstrak
Keterampilan dalam sebuah gerakan dapat dikuasai oleh seseorang apabila dilatih secara terus menerus untuk menghasilkan kemahiran gerakan dan otomatisasi dalam waktu tertentu. Sehingga untuk membentuk keterampilan sangat bergantung pada teknik dasar dalam hal ini adalah futsal. Tujuan dari penelitian ini adalah untuk mengetahui pengaruh dari metode serial practice dan random practice serta motivasi berprestasi terhadap keterampilan teknik dasar dalam futsal. Penelitian ini dilakukan pada atlet MA Mafatihul Huda, penelitian ini menggunakan treatment by level $2 \times 2$. Sampel terdiri dari 36 atlet. Teknik analisis data adalah analisis varians dua jalur (ANAVA) dan selanjutnya dilanjutkan dengan uji Tukey pada tingkat signifikansi $\alpha=.05$. Hasil penelitian ini menunjukkan bahwa (1) Nilai keterampilan teknik dasar dalam futsal pada perlakuan metode serial practice (A1) lebih tinggi dari nilai metode random practice (A2); (2) Terdapat pengaruh interaksi antara metode latihan (A) dan motivasi berprestasi (B) terhadap keterampilan teknik dasar dalam futsal; (3) Nilai keterampilan teknik dasar dalam futsal pada perlakuan metode serial practice motivasi berlatih tinggi $\left(A_{1} B_{1}\right)$ lebih tinggi dari nilai metode random practice motivasi berprestasi tinggi $\left(A_{2} B_{1}\right)$; (4) Nilai keterampilan teknik dasar dalam futsal pada perlakuan metode serial practice motivasi berprestasi rendah $\left(\mathrm{A}_{1} \mathrm{~B}_{2}\right)$ lebih rendah dari nilai metode random practice motivasi berprestasi rendah $\left(A_{2} B_{2}\right)$.
\end{abstract}

Catatan kunci : Practice, Motivasi Berprestasi, Teknik Dasar Futsal

\section{A. PENDAHULUAN}

Olahraga prestasi merupakan salah satu bidang yang perlu diperhatikan dalam pencapaiannya,karena olahraga mampu meningkatkan dan mengharumkan nama bangsa dipentas nasional dan internasional.Pembinaan prestasi olahraga berbagai disiplin ilmu terlibat didalamnya,termasuk penelitian yang dilakukan oleh para pakar olahraga dan kesehatan. Prestasi tidak akan datang sendirinya melainkan dengan perencanaan yang matang dan membutuhkan waktu yang lama. Namun demikian, beberapa olahraga masih ada persoalan cara dan teknik meningkatkan prestasi para siswa. 
Cabang olahraga futsal merupakan cabang olahraga permainan yang digemari dan dimainkan diseluruh Indonesia,tetapi prestasi futsal Indonesia sendiri pada saat sekarang ini sangat menurun, yang disebabkan karena masalah internal dalam federasi sepak bola indonesia. Permasalahan ini membuat para pemain tim nasional indonesia gagal mengharumkan dan membawa nama bangsa indonesia ke prestasi yang lebih tinggi di tingkat asia tenggara. Walaupun permasalahan futsal Indonesia belum membaik,tetapi permainan futsal sampai sekarang masih selalu dimainkan dan dilakukan pembinaan ditengah masyarakat Indonesia.

Aspek dasar permainan futsal sendiri tidak terlepas dari pembinaan dan peningkatan prestasi, selain sarana dan prasarana yang memadai juga membutuhkan pengawasan dan bimbingan dari pembina dan pelatih. Selain itu, pelatih harus mampu memahami perkembangan siswanya baik secara fisik maupun psikis. Pencapaian prestasi terbaik dalam futsal, ada dua faktor yang mempengaruhi dalam meraih suatu prestasi, faktor tersebut adalah faktor internal dan faktor eksternal. Faktor internal tersebut adalah keterampilan fisik, teknik, taktik dan mental siswa, dan faktor eksternal adalah yang timbul dari luar diri siswa, seperti pelatih, sarana dan prasarana, keluarga, organisasi, iklim, cuaca, makanan yang bergizi dan lain sebagainya.

Faktor yang mempengaruhi salah satunya faktor internal seperti teknik merupakan faktor utama keberhasilan penerapan konsep bermain, tanpa teknik yang baik maka sulit bagi setiap siswa untuk menguasai dan mengembangkan permainan dilapangan. Teknik dasar merupakan fundamental yang harus dikuasai oleh semua siswa agar dapat bermain futsal dengan terampil yang didasari keterampilan gerak. Latihan yang perlu dikembangkan pada anak usia muda adalah keterampilan teknik dasar yang benar. Pemain yang memiliki keterampilan teknik dasar futsal yang baik akan mampu menggunakannya dalam berbagai situasi, sehingga memberikan kemudahan dalam menerapkan taktik, kemudian mampu menciptakan kerjasama yang baik secara kelompok dan tim untuk meraih kemenangan.

Perkembangan futsal saat ini pada tingkatan usia remaja sangatlah pesat, itu tercermin pada banyaknya pembinaan futsal pada tingkat sekolah menengah atas yang dilakukan diluar jam sekolah atau dalam kegiatan ekstrakurikuler. Namun demikian, beberapa yang masih menjadi persoalan adalah cara dan teknik untuk meningkatkan prestasi para siswa. Untuk itu dalam meningkatkan prestasi dibutuhkan suatu 
keterampilan. Keterampilan sendiri merupakan kemampuan melaksanakan gerakangerakan secara efektif, cepat, dan tepat sesuai dengan tujuan yang dimaksud sehingga tidak mungkin disederhanakan lagi, Achmad Sofyan Hanif (2015 : 15). Keterampilan dalam sebuah gerakan dapat dikusai oleh seseorang apabila dilatih secara terus menerus untuk menghasilkan kemahiran gerakan dan otomatisasi dalam waktu tertentu. Sehingga untuk membentuk keterampilan sangat bergantung pada teknik dasar dalam hal ini adalah futsal. Teknik dasar dalam permainan futsal meliputi passing, dribbling dan shooting (menembak), Andri Irawan (2009 : 23). Untuk membentuk keterampilan yang baik dibutuhkan suatu metode melatih agar seluruh rangkaian aktivitas latihan tercapai. James Tangkudung dan Wahyuningtyas Puspitorini (2012 : 46) mendefinisikan "metode latihan merupakan suatu pelajaran untuk mengembangkan latihan, dimana kata metode itu digunakan untuk kondisi materi kegiatan.

Terdapat beberapa metode latihan yakni metode Metode serial practice merupakan pengaturan susunan praktek keterampilan yang berisi lebih dari satu aspek keterampilan dengan urutan pengaturan praktek yang selalu sama atau berurutan di setiap sesi latihan. Metode serial practice merukan metode latihan yang tingkatannya berada sesudah metodekeseluruhan, metode ini memiliki tinggkat kesulitan berada sebelum metode tersebut, dengan demikian serial practice dapat menjadi solusi dalam pengenalan metode random practice, karena tidak terlalu membebankan siswa dalam berlatih dan Metode Random Practice yang menghendaki siswa melakukan berbagai kegiatan latihan dalam satu waktu, sehingga siswa tidak pernah melakukan tugas gerakan yang sama secara berturut-turut.

Metode ini diperlukan siswa untuk melakukan berbagai bentuk gerakan atau teknik itu dalam satu waktu yang bersamaan.Siswa seolah berputar untuk melakukan semua bentuk keterampilan dengan cara acak, sehingga anak tidak melakukan tugas yang sama berturut-turut Namun untuk mnendukung terbentuknya prestasi tidak hanya dibutuhkan suatu metode latihan namun juga aspek psikologisnya. Aspek psikologi dalam penelitian ini merujuk pada motivasi berprestasi. McClelland dalam Sri wahyuni (2013 : 88-95) menyebutkan motivasi berprestasi adalah suatu pikiran yang berhubungan dengan bagaimana melakukan sesuatu dengan sebaik-baiknya bila dibandingkan dengan apa yang telah dilakukan sebelumnya dan lebih efisien dengan hasil maksimal. Dengan pendekatan psikologis diharapkan siswa dalam setiap 
penampilannya dapat memperlihatkan motivasi yang kuat untuk bermain sebaikbaiknya, sehingga dapat memenangkan pertandingan untuk mendapatkan prestasi tinggi. Sekolah-sekolah di Kabupaten Cirebon yang melakukan pembinaan secara teratur, terarah dan kontinyu, diantaranya MA Mafatihul Huda, MA Muhammadiyah, MA Islamic Center, MA Mambaul Ulum, dan masih banyak lagi sekolah - sekolah yang mempunyai satu tujuan yaitu membina, menciptakan dan menyalurkan bakat siswa yang mengikuti ekstrakurikuler futsal. MA Mafatihul Huda contohnya, adalah sekolah yang memiliki wadah atau kegiatan ekstrakurikuler dalam bidang futsal yang merupakan rangkaian pembinaan yang diharapkan mampu menciptakan siswa berprestasi dalam futsal ditingkat sekolah menengah atas. Untuk itu peneliti berusaha untuk mengkaji mengenai pengaruh metode latihan, motivasi, dan keterampilan teknik dasar futsal, hal ini dilakukan untuk dapat memberikan informasi terkait pengaruh yang diperoleh untuk meningkatkan prestasi dalam permainan futsal.

\section{B. METODOLOGI PENELITIAN}

Metode yang digunakan dalam penelitian ini adalah metode eksperimen lapangan,. Metode eksperimen adalah metode penelitian yang digunakan untuk mencari pengaruh treatment (perlakuan) tertentu. Penelitian ini terdiri dari variabel terikat yaitu keterampilan teknik dasar futsal dan variabel bebas perlakuan adalah metode latihan dan variabel bebas moderator yaitu motivasi berprestasi. Dalam penelitian ini ada perlakuan (Treatment), dengan demikian metode penelitian eksperimen dapat diartikan sebagai metode penelitian yang digunakan untuk mencari pengaruh perlakuan tertentu terhadap yang lain dalam kondisi yang terkendalikan.

Pengambilan sampel dalam penelitian ini ditetapkan seluruh atlet sebanyak 64 orang dalam populasi terjangkau. Adapun untuk sampel penelitian yaitu seluruh populasi terjangkau dilakukan dengan Verducci sampel 64 orang x 27\% =17,28 dibulatkan menjadi 18 orang. Jadi, sampel dalam penelitian ini adalah 36 orang atlet yang dibagi dalam kelompok $27 \%$ jumlah data skor tertinggi (18 orang) dan $27 \%$ skor terendah (18 orang). Sesuai dengan desain penelitian eksperimen treatment by level $2 \mathrm{x}$ 2 maka pengujian hipotesis dilakukan dengan menggunakan analysis of variance (ANAVA) dua jalur. Selanjutnya distribusi frekuensi divisualisasikan melalui tabel dan histogram. Selanjutnya, dilakukan pengujian persyaratan analisis yaitu. Uji Normalitas data menggunakan teknik uji Lilliefors. Dengan kriteria jika hasil pengujian 
menujukkan bahwa L Litung L $_{\text {tabel, }}$ maka data berasal dari populasi yang berdistribusi normal. Pengujian hipotesis menggunakan taraf signifikansi $\alpha=0,05$.

Uji homogenitas menggunakan uji Bartlett. Dengan kriteria, jika hasil pengujian

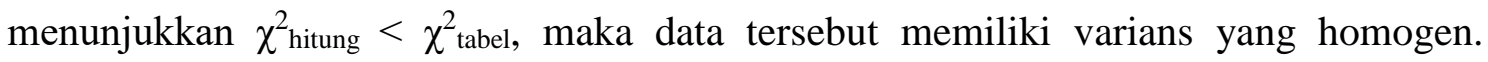
Pengujian hipotesis menggunakan taraf signifikansi $\alpha=0,05$. Uji normalitas dan uji homogenitas telah dilaksanakan selanjutnya baru dilakukan pengujian hipotesis penelitian dengan menggunakan analisis varians (ANAVA) dua jalur karena rancangan treatment by level dalam penelitian ini adalah $2 \times 2$. Apabila hasil analisis varians menunjukkan adanya pengaruh utama (main effect) antara variabel bebas terhadap variabel terikat dan adanya interaksi (simple effect) variabel bebas terhadap variabel terikat maka dilanjutkan dengan uji Tuckey sebagai uji lanjut untuk menentukan kelompok mana yang memiliki hasil keterampilan teknik dasar yang lebih baik yang dilakukan pada taraf signifikansi $\alpha=0,05$.

\section{HASHL DAN PEMBAHASAN PENELITIAN}

1. Hasil Penelitian

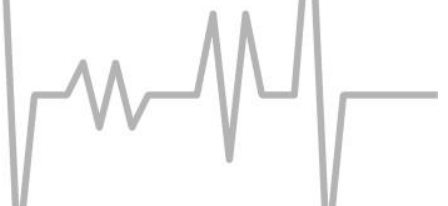

Data hasil keterampilan teknik dasar dalam futsal yang dipergunakan dalam analisis berupa data dari hasil penilaian keterampilan teknik dasardan nilai motivasi berpresatasi dengan menggunakan instrumen yang sudah baku serta teruji validitasnya (face validity) dan reliabilitasnya. Selanjutnya data keterampilan teknik dasar dan motivasi berprestasi dianalisis dengan mengumpulkan data dari masing-masing kelompok setelah mendapatkan perlakuan. Data hasil keterampilan teknik dasar dan motivasi berprestasi dalam futsal dapat dilihat pada tabel berikut ini :

Tabel 1

Hasil Keterampilan Teknik Dasar Dan Motivasi Berprestasi Dalam Futsal

\begin{tabular}{|c|c|c|}
\hline Metode Latihan & Serial Practice & Random Practice \\
\hline Tinggi & $\sum X=519$ & $\sum X=490$ \\
\hline & $\sum \mathrm{X}^{2}=30100$ & $\sum X^{2}=26863$ \\
\hline & $=57,69$ & $=54,45$ \\
\hline & $=4,30$ & $=4,79$ \\
\hline & $=9$ & $=9$ \\
\hline
\end{tabular}




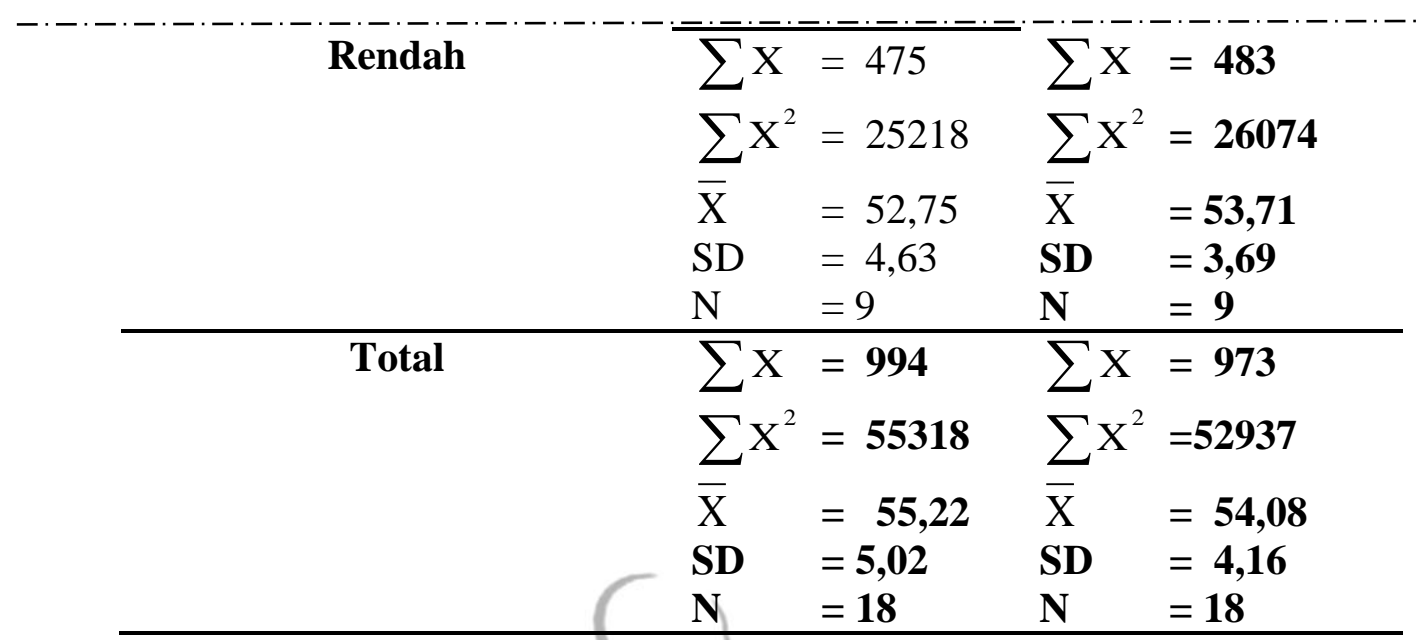

a. Hasil Keterampilan Teknik Dasar Futsal yang Diberikan Metode Latihan Serial Practice $\left(\mathrm{A}_{1}\right)$ Lebih Tinggi dari Metode Random Practice $\left(\mathrm{A}_{2}\right)$ Pada Atlet MA Mafatihul Huda Kabupaten Cirebon.

Berdasarkan hasil analisis varian (ANAVA) pada taraf signifikan $\alpha=0,05$, didapat $F_{\text {hitung }}=6,8018$ dan $F_{\text {tabel }}=4,11$. Dengan demikian $F_{\text {hitung }}>F_{\text {tabel }}\left(F_{\text {hitung }}=\right.$ $\left.6,8018>F_{\text {tabel }}=4,11\right)$. Sehingga $\mathrm{H}_{\mathrm{o}}$ ditolak $\left(\mathrm{F}_{0}>\mathrm{F}_{\mathrm{t}}\right)$ ini menunjukkan bahwa secara keseluruhan terdapat perbedaan hasil keterampilan teknik dasar futsal secara signifikan antara metode latihan serial practice dan metode random practice. Skor rerata kelompok metode latihan serial practice adalah $(\overline{\mathrm{X}}=55,22 ; \mathrm{SD}=5,02)$, sedangkan rerata skor kelompok metode random practice adalah $(\overline{\mathrm{X}}=54,08 ; \mathrm{SD}=4,16)$.

b. Terdapat Interaksi Antara Metode Latihan (A) dan Motivasi Berprestasi (B) Terhadap Keterampilan Teknik Dasar Futsal Atlet MA Mafatihul Huda Kabupaten Cirebon.

Berdasarkan hasil analisis varian dua arah, interaksi antara metode latihan dan motivasi berprestasi terhadap keterampilan teknik dasar futsal terlihat pada tabel perhitungan anava di atas. Harga hitung $F_{o}$ interaksi $(A X B)=5,1538$ dan $F_{t}=4,11$. Tampak bahwa $F_{\text {hitung }}>F_{\text {tabel }}\left(F_{\text {hitung }}=5,1538>F_{\text {tabel }}=4,11\right)$, sehingga $\mathrm{H}_{0}$ ditolak. dan $\mathrm{H}_{1}$ diterima dengan demikian dapat disimpulkan bahwa terdapat interaksi antara metode latihan dan motivasi berprestasi terhadap keterampilan teknik dasar futsal. Interaksi model latihan dengan motivasi berprestasi dapat dilihat pada gambar berikut : 


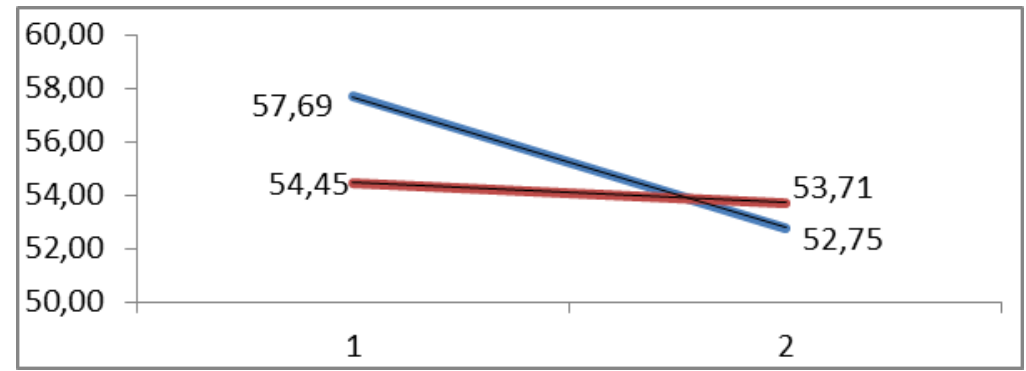

Gambar 1. Interaksi Model Latihan Dengan Motivasi Berprestasi

Berdasarkan data hasil penelitian diperoleh skor rata-rata hasil keterampilan teknik dasar futsal kelompok metode serial practice motivasi tinggi adalah sebesar 57,69 dan motivasi rendah 52,75. Untuk skor rata-rata hasi keterampilan teknik dasar futsalkelompok metode random practice motivasi tinggi adalah sebesar 54,45 dan motivasirendah 53,71.Rangkuman hasil uji lanjut dapat dilihat pada tabel dibawah ini.

Tabel 2

Ringkasan Hasil Perhitungan Uji Tuckey Skor Keterampilanteknik Dasar Dalam Futsal Pada Taraf $\alpha=0,05$.

\begin{tabular}{llll}
\hline $\begin{array}{l}\text { Pasangan kelompok yang } \\
\text { dibandingkan }\end{array}$ & Qhitung & $\mathbf{0 , 0 5}$ & Kesimpulan \\
\hline $\mathbf{A}_{1}(\mathbf{P 1})$ dengan $\mathbf{A}_{2}(\mathbf{P 2})$ & $5,77926^{*}$ & 2,86 & Signifikan \\
$\mathbf{A}_{1} \mathbf{B}_{1}(\mathbf{P 3})$ dengan $\mathbf{A}_{2} \mathbf{B}_{1}(\mathbf{P 4})$ & $5,96529^{*}$ & 3,79 & Signifikan \\
$\mathbf{A}_{1} \mathbf{B}_{2}(\mathbf{P 5})$ dengan $\mathbf{A}_{2} \mathbf{B}_{2}(\mathbf{P 6})$ & $1,76424^{*}$ & 3,79 & Tidak Signifikan \\
\hline
\end{tabular}

Keterangan :

* $\quad=$ Qhit $>$ Qtab signifikan pada taraf nyata $\alpha=0,05$

$\mathrm{P}_{1} \quad=$ kelompok metode serial practice

$\mathrm{P}_{2} \quad=$ kelompok metode random practice

$\mathrm{P}_{3} \quad=$ kelompok metode serial practice dengan motivasi berprestasi tinggi

$\mathrm{P}_{4} \quad=$ kelompok metode random practice dengan motivasi berprestasi tinggi

$\mathrm{P}_{5} \quad=$ kelompok metode serial practice dengan motivasi berprestasi rendah

$\mathrm{P}_{6} \quad=$ kelompok metoderandom practice dengan motivasi berprestasi rendah

c. Hasil Keterampilan Teknik Dasar Futsal dengan Metode Latihan Serial Practice Motivasi Berprestasi Tinggi $\left(\mathrm{A}_{1} \mathrm{~B}_{1}\right)$ Lebih Tinggi dari Metode Random Practice Motivasi Berprestasi Tinggi $\left(\mathrm{A}_{2} \mathrm{~B}_{1}\right)$ Atlet MA Mafatihul Huda Kabupaten Cirebon.

Metode serial practice dan random practicememberikan perbedaan terhadap keterampilan teknik dasar dalam futsalbagi kelompok yang memilikimotivasi berprestasirendah, namun perbedaan hasil tersebut tidak signifikan. Hal ini terbukti berdasarkan hasil uji lanjut dengan menggunakan uji Tuckey yang hasilnya sebagai berikut: 
Perbandingan Kelompok Metode Serial Practice Dan Metode Random Practice Bagi Kelompok Motivasi Rendah.

\begin{tabular}{ccccc}
\hline No & Kelompok yang Dibandingkan & $\mathbf{Q}_{\text {hitung }}$ & $\mathbf{Q}_{\text {tabel }}$ & Keterangan \\
\hline 1 & $\mathrm{P}_{5}$ dengan $\mathrm{P}_{6}$ & 1,76424 & 3,79 & Tidak Signifikan \\
\hline
\end{tabular}

Keterangan:

P5 = Kelompok motivasi berprestasirendah dengan metode serial practice.

P6 = Kelompok motivasi berprestasirendah dengan metode random practice.

Metode serial practice dan random practice memberikan perbedaan yang signifikan terhadap keterampilan teknik dasar futsal bagi kelompok yang memiliki motivasi tinggi. Perbedaan nilai kelompok metode latihan serial dan motivasi berprestasi tinggi $\left(\mathrm{P}_{3}\right)$ lebih tinggi dibanding dengan kelompok metode random dan motivasi berprestasi tinggi $\left(\mathrm{P}_{4}\right)$, diperoleh $\mathrm{Q}_{\mathrm{h}}=5,9652^{*}$ dan $\mathrm{Q}_{\mathrm{t}}=3,79$. Dengan demikian $\mathrm{Q}_{\mathrm{h}}$ lebih besar dari $\mathrm{Q}_{\mathrm{t}}$, sehingga $\mathrm{H}_{0}$ ditolak. Berdasarkan hasil perhitungan, didapat nilai rata-rata atlet yang memiliki motivasi berprestasi tinggi dengan menggunakan metode latihan serial practice $(\bar{X}=57,69 ; \mathrm{SD}=4,30)$ lebih tinggi dari nilai metode random practice $(\overrightarrow{\mathrm{X}}=54,45 ; \mathrm{SD}=4,79)$.

Perbedaan nilai kelompok/motivasi berprestasi tinggi dengan metode serial practice $\left(\mathrm{P}_{3}\right)$ dibanding dengan kelompok motivasi berprestasitinggidengan metode random practice $\left(\mathrm{P}_{4}\right)$, diperoleh $\mathrm{Q}_{\mathrm{h}}=5,96529 *$ dan $\mathrm{Q}_{\mathrm{t}}=3,79$. Dengan demikian $\mathrm{Q}_{\mathrm{h}}$ lebih besar dari $\mathrm{Q}_{\mathrm{t}}$, sehingga $\mathrm{H}_{0}$ ditolak.Berdasarkan hasil perhitungan, didapat nilai rata-rata atlet yang memilikimotivasi tinggi dengan menggunakan metode serial practice $(\overline{\mathrm{X}}=$ $57,69 ; \mathrm{SD}=4,30)$ lebih tinggi dari nilai metode random practice $(\overline{\mathrm{X}}=54,45 ; \mathrm{SD}=$ $4,79)$.

d. Hasil Keterampilan Teknik Dasar Futsal dengan Metode Latihan Serial Practice Motivasi Berprestasi Rendah $\left(\mathrm{A}_{1} \mathrm{~B}_{2}\right)$ Lebih Rendah dari Metode Random Practice Motivasi Berprestasi Rendah $\left(\mathrm{A}_{2} \mathrm{~B}_{2}\right)$ Atlet MA Mafatihul Huda Kabupaten Cirebon.

Keterampilan teknik dasar dalam futsal bagi kelompok yang memiliki motivasi berprestasi rendah, namun perbedaan hasil tersebut tidak signifikan. Hal ini terbukti berdasarkan hasil uji lanjut dengan menggunakan uji Tuckey yang hasilnya dapat dilihat dari tabel sebagai berikut: 


\section{Tabel 4}

Hasil Uji Lanjut Dengan Menggunakan Uji Tuckey

\begin{tabular}{ccccc}
\hline No & Kelompok yang dibandingkan & $\mathbf{Q}_{\text {hitung }}$ & $\mathbf{Q}_{\text {tabel }}$ & Keterangan \\
\hline 1 & $\mathrm{P}_{5}$ dengan $\mathrm{P}_{6}$ & 1,76424 & 3,79 & Tidak Signifikan \\
\hline
\end{tabular}

Keterangan:

P5 = Kelompok motivasi berprestasi rendah dengan metode serial practice .

P6 $=$ Kelompok motivasi berprestasi rendah dengan metode random practice

Metode serial practice dan random practice memberikan perbedaan terhadap keterampilan teknik dasar futsal bagi kelompok yang memiliki motivasi berprestasi rendah, namun perbedaan hasil tersebut tidak signifikan. Nilai kelompok motivasi berprestasi rendah dengan metode serial practice $\left(\mathrm{P}_{5}\right)$ lebih rendah dibanding kelompok motivasi berprestasi rendah dengan metode random practice $\left(\mathrm{P}_{6}\right)$ diperoleh hasil, $\mathrm{Q}_{\mathrm{o}}=$ 1,76424 dan $\mathrm{Q}_{\mathrm{t}}=3,79$. Artinya, data tersebut tidak ada alasan untuk menerima $\mathrm{H}_{0}$, Berdasarkan hasil perhitungan didapat nilai rata-rata atlet yang memiliki motivasi rendah dengan menggunakan metode serial practice $(\bar{X}=52,75 ; \mathrm{SD}=4,63)$ lebih rendah dari nilai metode random practice motivasi rendah $(\overrightarrow{\mathrm{X}} \triangleq \mid 53,71 ; \mathrm{SD}=3,69)$.

2. Pembahasan Hasil Penelitian

Dari hasil pengujian keempat rumusan hipotesis ternyata hasilnya menunjukkan bahwa hipotesis 1 (satu), 2 (dua),3 (tiga ) tersebut teruji. Sedangkan rumusan hipotesis yang ke 4 (empat) menunjukkan bahwa secara statistik tidak terdapat perbedaan yang signifikan. Secara rata-rata bahwa skor metode latihan serial practice lebih tinggi dari pada metode random practice terhadap hasil keterampilan teknik dasar futsal. Hal ini menunjukkan bahwa kedua metode latihan tersebut memberikan pengaruh yang berbeda terhadap hasil keterampilan teknik dasar futsal. Hipotesis keempat menunjukkan tidak terbukti atau belum dapat teruji kebenarannya karena tidak didukung oleh data yang terkumpul. Hal ini tidak sesuai dengan kajian teori dan kerangka berfikir yang telah dikemukakan tetap masih menjadi dugaan karena belum dapat dibuktikan secara empirik. Dengan demikian, diperlukan pembahasan terhadap berbagai kemungkinan yang menyebabkan tidak terbuktinya hipotesisi tersebut.

Adapun kemungkinan yang terjadi sebagai berikut:

1. Waktu latihan yang sebentar diduga sebagai salah satu penyebab tidak terbuktinya hipotesis keempat. 
2. Sarana prasarana belajar disekolah kurang memadai mengakibatkan kurang efektifinya latihan yang dilakukan.

3. Diduga atlet ada yang melakukan aktivitas olahraga lain diluar perlakuan yang diberikan, walaupun sebelum penelitian dimulai telah diberitahukan agar jangan melakukan kegiatan olahraga selama masa penelitian.

4. Faktor fisik dimungkinkan berpengaruh terhadap rendahnya komponen fisik paraatlet.

5. Minat atlet merupakan satu unsur psikologi yang diduga turut mempengaruhi penelitian, dimana minat merupakan salah satu pendorong seseorang untuk memiliki suatu aktivitas tertentu. Jika seseorang memiliki minat terhadap suatu aktivitas, maka ia akan lebih serius untuk melakukan aktivitas tersebut.

Secara keseluruhan maka metode latihan serial practice memiliki pengaruh yang lebih baik dibanding denganrandom practice. Sedangkan bagi yang memiliki motivasitinggi hendaknya memilih metode serial practicejika ingin meningkatkan hasil keterampilan teknik dasar futsal. Sedangkan bagi yang memilikimotivasirendah, dapat diberikan kedua metode latihan tersebut untuk meningkatkan hasil keterampilan teknik dasar futsal, tetapi cenderung akan lebih baik jika diberikan metode latihan random practice, hal ini disebabkan perbedaan jumlah rata-ratanya.

\section{KESIMPULAN}

Penelitian ini menggunakan metode eksperimen yang melibatkan variabel bebas, yaitu metode latihan serial dan metode latihan random, variabel atribut adalah motivasi berprestasi, sedangkan sebagai variabel terikatnya adalah keterampilan teknik dasar futsal pada atlet MA Mafatihul Huda Kabupaten Cirebon. Berdasarkan hasil analisis data, hasil pengujian hipotesis dan hasil pembahasan penelitian yang telah diperoleh maka dapat dijelaskan beberapa kesimpulan, sebagai berikut:

1. Metode latihan serial memiliki pengaruh yang lebih tinggi hasil nya daripada metode random terhadap keterampilan teknik dasar futsal pada atlet MA Mafatihul Huda Kabupaten Cirebon.

2. Terdapat interaksi antara metode latihan dan motivasi berprestasi terhadap keterampilan teknik dasar futsal pada atlet MA Mafatihul Huda Kabupaten Cirebon. 
3. Metode latihan serial motivasi berprestasi tinggi memiliki pengaruh yang lebih tinggi hasil nya daripada metode latihan random motivasi berprestasi tinggi terhadap keterampilan teknik dasar futsal pada atlet MA Mafatihul Huda Kabupaten Cirebon.

4. Metode latihan serial motivasi berprestasi rendah memiliki pengaruh yang lebih rendah hasil nya daripada metode latihan random motivasi berprestasi rendah terhadap keterampilan teknik dasar futsal pada atlet MA Mafatihul Huda Kabupaten Cirebon.

\section{Daftar Pustaka}

Asmar, Jaya. 2008. Futsal. Pustaka Timur.

Hamzah B. Uno. 2008. Teori Motivasi dan Pengukurannya. Jakarta: Bumi Aksara.

Hanif, Achmad Sofyan. 2015. Kepelatihan Dasar Sepak Takraw. Jakarta: PT. RajaGrafindo

Haryani, Ratna. 2014. Motivasi Berprestasi pada Mahasiswa Berprestasi dari Keluarga Tidak Mampu Secara Ekonomi" Jurnal Psikologi Pendidikan dan Perkembangan Vol 3 , No. 01 , April 2014.

Irawan, Andri. 2009. Teknik Dasar Modern Futsal. Jakarta: Pena Pundi Aksara.

James Tangkudung \& wahyuningtyas puspitorini. 2012. Kepelatihan Olahraga. Jakarta: Cerdas Jaya.

Johansyah Lubis. 2013. Panduan Praktis Penyusunan Program Latihan Jakarta: PT. RajaGrafindo Persada.

John D. Tenang. 2008. Mahir Bermain Fusal .Dar Mizan.

Lhaksana, Justinus. 2011. Futsal Modern. Jakarta: Be Champion.

Wahyuni, Sri. 2013. Hubungan Efikasi Diri dan Regulasi Emosi dengan Motivasi Berprestasi Pada Siswa SMK Negeri 1 Samarinda. e-Journal Psikologi Fisip UNMUL, Vol.1, No.1, Tahun 2013. 